Maja Chacińska

Uniwersytet Gdański

\title{
Saamowie i ich kultura codzienna w filmie i reportażu z pierwszej połowy XX wieku - rekonstrukcja tożsamości w tekstach kultury
}

\author{
Saami People and Their Everyday Culture in Film and Non-fiction \\ from the First Half of the Twentieth Century
}

The Saami people are indigenous people and ethnic minorities living in Sápmi, which encompasses the northern areas of Finland, Norway, Sweden, and the Kola Peninsula in Russia. At the beginning of the twentieth century, interest in Saami began to grow among Swedish researchers, journalists, writers, and film-makers (Jordahl 2014). The aim of this article is to compare the depiction of the attributes of Sami identity as reconstructed in cultural texts from the first half of the twentieth century. The main subject of the analysis is the Swedish feature film Midnattssolens son (The Son of the Midnight Sun) directed by Rolf Husberg and Thor L. Brooks from 1939 and the non-fiction book by the Swedish journalist Ester Blenda Nordström Kåtornas folk (People of the Cots) from 1916.

Key words: Saami, indigenous, film, non-fiction book, Sweden, ethnic identity

Słowa klucze: Saamowie, lud rdzenny, film, reportaż, Szwecja, tożsamość etniczna

\section{Wstęp}

Saamowie to rdzenna ludność i mniejszość etniczna zamieszkująca Sápmi, czyli północne obszary Finlandii, Norwegii i Szwecji oraz Półwysep Kolski w Rosji. Pojęcie Sápmi obejmuje zarówno obszar geograficzny, jak i ludzi (Samiskt informationscentrum 2021a). Saamowie są jedyną rdzenną ludnością w Europie. Relacje medialne, zarówno w postaci fikcji, jak i reportażu, zawsze były bardzo ważne dla postrzegania tej mniejszości etnicznej, a rozwój mediów audiowizualnych $\mathrm{w}$ pierwszej połowie XX wieku ułatwił szerszej widowni dostęp do wiedzy o niej. Ponadto na początku XX wieku zaczęło wzrastać zainteresowanie Saamami wśród Szwedów: „Badacze, dziennikarze, filmowcy, pisarze i politycy ciągnęli tam [do Laponii - przyp. M.Ch.]" (Jordahl 2014). 
Celem niniejszego artykułu jest porównanie rekonstrukcji atrybutów tożsamości etnicznej Saamów w dwóch tekstach kultury¹: w szwedzkim filmie fabularnym Syn nocnego słońca (Midnattssolens son) w reżyserii Rolfa Husberga i Thora L. Brooksa z 1939 roku oraz w pochodzącym z 1916 roku reportażu Kåtornas folk (Lud namiotów) szwedzkiej dziennikarki Ester Blendy Nordström. Reportaż Nordström był bardzo popularny w Szwecji i tłumaczono go na inne języki, natomiast film mógł mieć duży wpływ na postrzeganie Saamów wśród zwykłych Szwedów. Interesujące jest dla mnie sprawdzenie, na ile rekonstrukcja tych atrybutów tożsamości w fikcji zgadza się z przedstawioną w literaturze faktu. Oba teksty kultury są w Polsce prawie nieznane ${ }^{2}$.

W artykule używam nazwy Saamowie, która jest jedyną akceptowaną przez tę ludność. Natomiast zarówno w filmie, jak i w reportażu używana jest dawna i uważana obecnie za dyskryminującą, kolonialną i obraźliwą nazwa Lapończycy (szw. lapp, lappar), z której w niniejszym artykule korzystam jedynie w cytatach.

\section{Film i książka}

Film Syn nocnego słońca (1939) to dramat społeczny przedstawiający życie Saamów na północy Szwecji w okolicach Kiruny i Karesuando. Główny bohater, którym jest Nila, hodowca reniferów, zmaga się z wieloma problemami: przetrzebieniem stada z powodu srogiej zimy, kradzieżami reniferów przez Finów i Saamów, chorobą ciężarnej żony i w końcu pomówieniem o zabójstwo. Wszystko kończy się jednak dobrze dzięki łasce króla szwedzkiego, ale również dzięki wspólnocie i poczuciu solidarności Saamów. W filmie jest wiele trzymających w napięciu scen ucieczki i pogoni oraz walk, w których biorą udział Saamowie naturszczycy i ich stada ${ }^{3}$.

Krytycy chwalili film za piękne zdjęcia, trzymające w napięciu sceny akcji oraz za realizm w ukazywaniu Saamów: „Widzieliśmy już filmy o Lapończykach. Ale były to romantyczne opowieści, niezbyt prawdziwe, w których Lapończyków grali kapryśni aktorzy ze Sztokholmu. Tutaj wszystko jest autentyczne" (Midnattssolensson 2021, tłum. M.Ch.).

Rune Waldekranz (pseud. Roderick) uznaje scenę, w której stado reniferów toruje Saamom drogę do szpitala wśród szalejącej burzy śnieżnej, za podkreślającą więź Saamów z reniferami i „najpiękniejszą, jaką widział na ekranie” (Roderic 1939: 14, tłum. M.Ch.). Natomiast recenzent Dagens Nyheter zachwycał się talentem aktorskim Saamów występujących w głównych rolach (Midnattssolensson 2021).

Książka dziennikarki Ester Blendy Nordström Kåtornas folk jest reportażem opisującym pół roku z życia autorki wśród Saamów. W 1914 roku Nordström

\footnotetext{
O rekonstrukcji tożsamości zbiorowej w tekstach kultury zob. Wójcicka (2016); Legare (2013).

Reportaż nie był tłumaczony na język polski, a film pojawił się na platformie Netflix w $2021 \mathrm{r}$.

W napisach początkowych umieszczono nazwiska Saamów grających trzy główne postacie (Marję,

Nilę i Labbę), co nie było tak oczywiste w okresie, gdy powstał film.
} 
pracowała dla szwedzkiej gazety Svenska Dagbladet i odbyła podróż do Kiruny i Laponii, aby napisać cykl artykułów o zwyczajach i tradycjach Saamów. Nordström zafascynowała prostota życia Saamów i zachwyciła przyroda północnej Szwecji (Bremmer 2017: 98-99). Dziennikarka postanowiła zatrudnić się w tzw. szkole nomadycznej dla dzieci saamskich (szkoły te funkcjonowały od $1913 \mathrm{r}$. i są omówione w dalszej części artykułu), co oznaczało, że spędziła z dużą grupą Saamów pół roku, wędrując z Jukkasjärvi do Norwegii, gdzie rozbito obóz letni. W obozie znajdowała się szkoła dla czternaściorga saamskich dzieci w różnym wieku.

Recenzje krytyków i czytelników pierwszego wydania książki były bardzo pozytywne, ale biografka Nordström zaznacza, że wielu recenzentów przyjaźniło się z autorką, na przykład pisarka Elin Wägner, która napisała recenzję dla dziennika Dagens Nyheter (Bremmer 2017: 140-141). Więcej informacji na temat ówczesnego i współczesnego odbioru książki znajduje się w dalszej części artykułu.

Film i książkę dzieli ponad dwadzieścia lat, niemniej zmiany w kulturze i tradycjach hodowców reniferów na obszarach Sápmi nie były w tym okresie znaczące. W tym czasie wprowadzono jednak regulacje, które utrudniły wypas reniferów, na przykład podpisana w 1919 roku przez Norwegię i Szwecję konwencja pozbawiła Saamów części pastwisk i spowodowała przymusowe przesiedlenia. W 1917 roku wprowadzono natomiast obligatoryjne szkoły stacjonarne, początkowo w namiotach, a później również w budynkach $z$ internatem, przez społeczność saamską krytykowane za zakaz mówienia po saamsku i pogłębianie segregacji (Oscarsson 2016: 90). Znaczne pogorszenie kwestii autonomii Saamów na ich terenach spowodowała też szwedzka ustawa o wypasie reniferów z 1928 roku (Samiskt informationscentrum 2021b).

W analizie będę korzystała głównie z dwóch źródeł: książki reportażowej Kåtornas folk i filmu fabularnego Syn nocnego stońca (jeżeli nie podaję inaczej). W związku z tym w nawiasach podawane będą jedynie numery stron książki oraz minuty i sekundy filmu. Wszystkie fragmenty reportażu oraz wypowiedzi bohaterów filmu są podane w moim tłumaczeniu.

\section{Analiza}

W tej części artykułu porównuję elementy rekonstruowanej tożsamości saamskiej w filmie i w reportażu. Przyjmuję, że jest to tożsamość grupy etnicznej, a za taką uznaję za Emmy G. Irobi „wspólnotę, której członków łączą więzy językowe i kulturowe, wśród nich historia, tradycja, wierzenia i mitologia, a także wspólne pochodzenie” (Irobi 2009: 232). Do takich grup Donald L. Horowitz zalicza „plemiona, rasy ${ }^{4}$, narodowości i kasty" (1985: 53, tłum. M.Ch.)

4 Należy podkreślić, że Horowitz pisał swoją monografię w 1985 r., podczas gdy w XXI w. wielu badaczy uznaje, że nauka, przede wszystkim genetyka, nie potwierdza istnienia ras ludzkich. Trwa debata naukowa na ten temat, zob. Mccann-Mortimer, Augoustinos i Lecouteur (2004). 
Z przeprowadzonego przez Kandrę Chandra porównania różnych definicji tożsamości etnicznej autorstwa kilku badaczy (Maxa Webera, Daniela Horowitza, Jamesa D. Fearona, David D. Laitina i Anthony'ego D. Smitha) można wywnioskować, że duże znaczenie w tego typu tożsamości ma wspólne pochodzenie oparte niekoniecznie na więzach krwi, ale przede wszystkim na wspólnych tradycjach, podobieństwie fizycznym i pamięci zbiorowej (Chandra 2006: 402-403). To pochodzenie jest różnie nazywane przez poszczególnych badaczy: u Webera to common descent, u Horowitza collective ancestry, u Smitha common ancestry, a u Fearona i Laitina natural history (Chandra 2006: 402-403). Renata Suchocka zalicza tego typu atrybuty tożsamości etnicznej do warstwy behawioralnej tożsamości i klasyfikuje je jako znajomość języka przodków, religię, znajomość kultury przodków, kontakty ze zbiorowością oraz zatrudnienie i zamieszkanie (Suchocka 2017: 12).

Biorąc pod uwagę kryteria zawarte w tych definicjach, wyodrębniłam konkretne kategorie, według których porównuję rekonstrukcję tożsamości saamskiej w obu tekstach kultury. Każdy z porównywanych elementów jest przyporządkowany danej kategorii, takiej jak: tradycje, religia, język, zatrudnienie i zamieszkanie. W definicjach podkreśla się jeszcze kontakty ze zbiorowością, które w przypadku obu analizowanych przeze mnie tekstów kultury przenikają wszystkie kategorie Saamowie w swoich wędrówkach bardzo często mają kontakty z wieloma saamskimi grupami na terenie Szwecji i Norwegii. Weber wspomina również o wadze „pamięci kolonizacji i migracji” (Chandra 2006: 402, tłum. M.Ch.). Ten aspekt nie jest bezpośrednio poruszany w obu analizowanych tekstach kultury, ale w ich późniejszych recenzjach, do czego powrócę pod koniec artykułu.

\section{Strój i dom (tradycje)}

Zarówno w książce, jak i w filmie Saamowie nosili na co dzień tradycyjny strój kolt w wersji codziennej. Kobiety zakładały długie kolty, mężczyźni kolty przed kolana i dopasowane spodnie (sam. säpäkke). Mężczyźni i kobiety nosili grube paski i specjalne nakrycia głowy - kobiety zakładały czepki, a mężczyźni czapki $\mathrm{z}$ wielkimi pomponami. W filmie rzadziej niż w książce występują mężczyźni w czworokątnych czapkach (podobnych kształtem do krakowskich) bez pompona ${ }^{5}$. W filmie Syn nocnego słońca już w pierwszej scenie widzimy Nilę w tradycyjnym stroju, z lassem przewieszonym przez ramię, na nartach i z jednym kijkiem (1:50). Nordström tak opisuje stroje: „Nikke idzie z nimi, najdumniejszy z nich wszystkich - lasso przewieszone przez ramię, czapka na skos, a olbrzymi pompon kołysze się nad uchem" (s. 16). Zarówno kobiety, jak i mężczyźni nosili pasy haftowane lub zdobione srebrnymi napami (s. 29, 2:19) i buty zrobione ze skóry reniferów

Ten rodzaj nakrycia głowy jest po szwedzku nazywany czapką czterech wiatrów (de fyra vindarnas mössa), a przez Saamów z Karesuando sávká. 
i dodatkowo wypchane słomą (s. 19, 19:51). Nordström opisuje również kolty z futra noszone w filmie przez Nilę i Labbę w scenie oświadczyn, na które „Nila wystroił się jak w święto" (2:17).

Niektóre kobiety nosiły korale i ozdobne broszki. W filmie Syn nocnego słońca w scenie oświadczyn widać kilka sznurów korali na szyi Marji, natomiast matka Marji nie ma żadnych ozdób (4:13). Nordström wyjaśnia w swoim reportażu, że księża i kaznodzieje surowego laestadianizmu wyznawanego przez grupę Saamów, z którymi wędrowała, uważali noszenie tego typu ozdób za grzech. Niektóre młodsze kobiety nosiły korale, natomiast starsze starały się być bardziej pobożne. Nordström opisuje, że ozdoby znikały, gdy obóz odwiedzał wędrowny pastor, ale kiedy wyjeżdżał, „po paru tygodniach zaczęły się pojawiać tu koraliki, tam broszka i wkrótce wszystko wróciło do normy" (s. 235).

Kobiety nosiły również na koltach chusty, często z długimi frędzlami, i broszki, którymi je spinały. W filmie kobiety i dziewczynki noszą kwieciste chusty w scenie w szkole saamskiej (16:43), na ślubie i weselu (od 24:00) i gdy Saamowie bawią się w przyjezdnym wesołym miasteczku (41:33). Przed ślubem matka Marji spina jej białą chustę dwoma srebrnymi broszkami, natomiast na co dzień kobieta ma chustę spiętą skromniejszą spinką lub związaną. Nordström wielokrotnie opisuje takie właśnie chusty na kartach swojej książki (np. s. 43, 83, 169). Dziennikarka pisze również o bardziej odświętnych chustach, określając je jako „chusty do kościoła” (szw. Kyrkduk, s. 230). Tego typu stroje można również zobaczyć na nielicznych fotografiach i fragmentach filmów, na których widać Nordström wśród Saamów, na przykład w filmie dokumentalnym Ester Blenda - walraffande piga (2016, 20:23).

Występujące w filmie dzieci saamskie są ubrane podobnie jak dorośli (39:57). W książce autorka pisze, że stroje dzieci są „wierną kopią strojów dorosłych: buty z materiału, säpäkke, kolty, chusty, pasy - wszystko dokładnie tak jak dorośli” (s. 31). Na filmie widać to szczególnie w scenie, w której z namiotu wychodzą jego mieszkańcy: dwie kobiety, dwóch mężczyzn i piątka dzieci. Dziewczynki, również te małe, noszone jeszcze na rękach dorosłych, są ubrane dokładnie tak jak kobiety, a chłopcy tak jak mężczyźni (40:00).

Autorka reportażu Kåtornas folk twierdziła, że mężczyźni spali w nakryciach głowy i zdejmowali je tylko w trakcie posiłków (s. 65). Mężczyźni w filmie rzeczywiście w trakcie jedzenia i picia nie noszą czapek, natomiast w trakcie sceny przedstawiającej śpiącego Nilę widzimy, że śpi bez nakrycia głowy, w przeciwieństwie do Marji i jej matki, które śpią w czepkach (29:59).

Saamskie namioty w języku szwedzkim noszą nazwę kåta. Podczas wędrówki i w obozie letnim każda rodzina miała własny namiot. Zarówno w filmie, jak i w książce możemy zauważyć, że przy złej pogodzie rozstawiano tylko jeden namiot dla całej wędrującej wspólnie grupy (s. 26, 11:18).

Opisy Nordström i sceny filmowe ukazują namioty jako konstrukcje złożone z drewnianego stelażu pokrytego materiałem. Do składania i rozkładnia takiego namiotu służyła drewniana drabinka (s. 103-104). W filmie wyraźnie widać tę 
konstrukcję, gdy Nila i Marja muszą szybko złożyć namiot z powodu burzy śnieżnej (9:07). Wierzchołek namiotu pozostawał otwarty, ponieważ pod nim znajdowało się palenisko (11:06). Wnętrze namiotu saamskiego jest w filmie pokazane tylko dwa razy: podczas ceremonii oświadczyn (2:33) i podczas odpoczynku nocnego po burzy śnieżnej (11:27). Tymczasem mieszkająca przez pół roku z Saamami autorka Kåtornas folk opisuje je wielokrotnie, ponieważ większość czasu spędza we własnym namiocie lub gości u innych. Dowiadujemy się na przykład, że kuchnia znajdowała się zawsze naprzeciwko wejścia do namiotu, a podłogę stanowiły gałązki brzozowe i skóry reniferów (s. 28), co widać również w filmie (11:27).

Nordström dużo miejsca poświęca kwestii drewna na opał, ponieważ podczas wędrówki do letniego obozu dostęp do niego był warunkiem przeżycia. W skrajnych sytuacjach, jeżeli w okolicy nie było możliwości zebrania drewna i z powodu burzy śnieżnej nie można było wędrować do innego miejsca, Saamowie musieli palić swój dobytek, na przykład sanie (s. 37). W filmie nie ma tego typu szczegółów, ale w namiocie Marji widać rozłożone gałązki i pieńki brzozowe (3:02), a z reportażu Nordström wynika, że brzoza była najczęściej używanym drewnem opałowym (np. s. 19, 187).

Ciekawym saamskim elementem wyposażenia były kołyski dla niemowląt (szw. vagga, sam. gïerhkeme, gietkka, gierkav), które można było przytroczyć do boku renifera, położyć na saniach, nieść na plecach lub na ramieniu. Kołyska była zrobiona z drewna, obłożona skórą i przykrywana materiałem. W filmie Syn nocnego słońca widzimy ją $\mathrm{w}$ dwóch scenach: na weselu jedna $\mathrm{z}$ kobiet siedzi nieco $\mathrm{z}$ boku, trzyma kołyskę na kolanach i zagląda do płaczącego niemowlęcia (27:37). Druga scena to ostatnie minuty filmu: Nila uwolniony $\mathrm{z}$ więzienia dzięki wstawiennictwu króla wędruje z Marją i stadem reniferów. Nila prowadzi renifera i dopiero po chwili widzimy, że do boku zwierzęcia przytroczona jest kołyska, z której Marja wyciąga płaczące niemowlę w kolcie i czapeczce $z$ dużym pomponem (1:18:15). Nordström nazywa kołyskę komson (od norweskiego słowa komse oznaczającego właśnie saamską kołyskę), kiedy opisuje dzieci jednej z gospodyń o imieniu Gate. Najmłodsza dziewczynka ma zaledwie kilka miesięcy $i$ „najczęściej jej nie widać, co nie znaczy, że nie słychać z głębokiej i dobrze zawiązanej kołyski [komson]" (s. 30). Rzeczywiście, kiedy w filmie Marja wyjmuje dziecko z kołyski, widać, że jest ona zasznurowana rzemieniami, które miały uchronić niemowlę przed wypadnięciem (1:18:01).

\section{Zwyczaje związane z posiłkami (tradycje)}

Według Nordström Saamowie pili bardzo dużo kawy gotowanej w dzbanku na palenisku. Po przybyciu na miejsce obozu i rozpaleniu ognia najpierw parzono kawę. Także gości przychodzących do namiotu od razu częstowano kawą (np. s. 19, 28, 110). W filmie występuje również pojęcie „kawa oświadczalna” (szw. friarkaffe). Nila przynosi woreczek z kawą, którą matce Marji przekazuje posłaniec - starszy mężczyzna występujący w imieniu oświadczającego się (2:54). 
W reportażu z 1916 roku nie ukazano żadnych oświadczyn, więc nie ma tam potwierdzenia tego zwyczaju, natomiast opisany jest woreczek na kawę podobny do tego z filmu: „gładki i mały, zrobiony ze skóry, która była kiedyś jasnobrązowa, ale przez dekady sadza i tłuszcz utworzyły na niej piękną i błyszczącą patynę i teraz jest całkiem czarny" (s. 68).

Według opisów zawartych w reportażu Kåtornas folk zwyczajowo to gospodyni pierwsza kosztowała kawy, żeby sprawdzić, czy jest smaczna (s. 111), w filmie jednak ten rytuał nie jest pokazany, a w scenie oświadczyn to posłaniec Labba i Nila jako pierwsi zaczynają pić kawę (s. 3:41).

Nordström opisuje wiele sytuacji, gdy miała okazję gościć sąsiadów w swoim namiocie lub gdy sama była w gościnie. Saamowie odwiedzali się, gdy mieli jakąś sprawę do załatwienia lub po prostu by porozmawiać, lub - jak w przypadku kobiet - posiedzieć wspólnie przy robótkach. Przy takich okazjach wypijano bardzo dużo kawy, natomiast gdy goście zostawali dłużej lub wiadomo było, że przybyli z daleka, gospodyni częstowała ich posiłkiem (s. 95, 111).

W reportażu opisano wiele sytuacji spożywania posiłków, ale bez podawania szczegółów. W filmie natomiast przedstawiono Saamów jedzących tylko w jednej, odświętnej sytuacji, czyli w trakcie wesela. Posiłek weselny składał się z gotowanego mięsa i ziemniaków z sosem oraz rodzaju kisielu czy kompotu z owocami na deser, na stołach był również chleb zwykły i chrupki oraz masło. W tej scenie większość Saamów używała do jedzenia łyżek i własnych noży. Niektóre kobiety jadły za pomocą widelców i noży nakrytych do stołu (27:26). Saamowie jedli spokojnie, rozmawiając i popijając kawę, ale widać było, że posiłek im smakował. Tymczasem Nordström opisuje, że zarówno mężczyźni, jak i kobiety jedli „powoli i z godnością, bez śladu pośpiechu czy apetytu” (s. 111). W reportażu Nordström czytamy również, że każdy nosił ze sobą własne sztućce (łyżkę i nóż), których używał w trakcie posiłku (s. 82-83).

Potrawy, które wymienia pisarka, to przede wszystkim gotowane, wędzone i suszone mięso reniferów oraz chleb żytni pieczony bez drożdży (s. 67). Podobny chleb leży w chacie Marji w scenie oświadczyn (2:59). Nordström wspomina również o kozim mleku i suszonym mleku reniferów, które dodawano do kawy, a także o specjalnym serze rozpuszczanym w kawie (s. 67, s. 191) .

Zwyczaj ten istnieje do dziś i jest przedstawiany we współczesnych produkcjach fabularnych, np. we francusko-szwedzkim serialu Midnight Sun (2016, np. E03, 19:20) i szwedzkim filmie o Saamach w latach 30. XX w. Krew Saamów (2016, 01:09:33). 


\section{Praca i gospodarstwo (zatrudnienie)}

Saamowie przedstawieni w filmie i w książce utrzymują się z hodowli reniferów. Nila, główny bohater filmu, zatrudnia się na jakiś czas w tartaku w Kirunie, ponieważ ciężka zima i dzikie zwierzęta (zarówno w książce, jak i filmie głównymi wrogami reniferów są rosmaki i wilki) przetrzebiły jego stado. Po zaręczynach Nila musi powiększyć stado, aby utrzymać przyszłą żonę i dzieci. Jedynie do tej pracy Nila zdjął kolt i kupił sobie zwykłe szwedzkie ubranie (14:55). W tym czasie Marja pracuje jako nauczycielka w saamskiej szkole (16:21).

Nordström wielokrotnie podkreśla w książce znaczenie hodowli reniferów w życiu Saamów. Początkowo wędrówka z Saamami była dla niej bardzo ciężka z powodu pogody, ale i długości odcinków, które przebywano każdego dnia. Autorka wyczekuje zmęczenia reniferów, ponieważ tylko to decyduje o postoju: „Ludzie nic nie znaczą" (s. 11).

Nila wraca do hodowli reniferów, gdy tylko pozwala mu na to jego sytuacja. Praca związana z hodowlą i przemieszczanie się wraz ze zmianą pór roku i zmianą pastwisk są pokazane w filmie i opisane w książce bardzo podobnie. Zarówno w książce, jak i w filmie wędrujący lub obozujący Saamowie często łączą się w większe grupy, na przykład Nordström wędrowała z grupą Saamów, w skład której wchodziła starsza para Nikke i Elle oraz rodziny ich synów i córek (s. 16). W filmie Nila i Marja wędrują sami i dopiero na wypas letni łączą się z większą grupą Saamów (40:00). Marja i Nila sami doglądają swojego stada, natomiast Nikke i Elle, których Nordström opisuje jako najbogatszych Saamów dystryktu (s. 16), zatrudniają do tego parobków, na zmianę czuwających bezpośrednio przy stadzie (s. 40).

I w filmie, i w książce widać dumę z posiadanych stad i to, że renifery są dla Saamów kluczowym elementem życia. Po ślubie, gdy Nila i Marja wyruszają $\mathrm{z}$ reniferami na letnie pastwiska, mężczyzna $\mathrm{z}$ dumą pokazuje żonie swoje stado (31:10). W książce Nordström często zwraca uwagę na to, jaką wartością są dla Saamów renifery, które są głównym tematem ich rozmów: „O czym innym mieliby rozmawiać, czym innym mieliby się martwić jak nie jedynym środkiem do życia, jaki mają" (s. 34, tłum. M.Ch.). Nila i Marja cieszą się, gdy widzą młode swoich reniferów (twórcy pokazują widzowi prawdziwe nowo narodzone cielęta, które ledwo trzymają się na nogach, 35:23). W książce największą radością jest powrót stad z norweskich pastwisk do obozu letniego (s. 248). Stada zatrzymują się około pięciu kilometrów od obozu, gdzie młode będą znakowane. Zwyczaj odpowiadający polskiemu kolczykowaniu zwierząt hodowlanych przetrwał do dzisiaj i jest opisany w książce oraz pokazany w filmie (s. 254-255, 57:58). Młode renifery są wyłapywane za pomocą lassa, kładzione na ziemi, a następnie ich właściciele szybko wykrawają nożem swój unikalny znak na skrajnej części małżowiny usznej zwierzęcia.

Znakowanie było nie tylko formą odróżnienia reniferów, gdy były wspólnie wypasane, ale również w razie kradzieży. W książce Kåtornas folk wspomina się o norweskich Saamach osadzonych w więzieniu w Trondheim za „kradzież 
reniferów i bójki z nożem” (s. 158). Twórcy filmu pokazali kradzież reniferów przez Fina Juhę Heikolę i szwedzkich Saamów. Po złapaniu sprawców, którzy akurat dzielili mięso skradzionych zwierząt, Nila odnajduje zakopane w śniegu futro i po znaczniku na skórze $\mathrm{z}$ ucha rozpoznaje swoje renifery (1:00:10).

Według opisów Nordström kobiety zajmowały się zbieraniem drewna, przygotowywaniem posiłków i opieką nad dziećmi, ale również pomagały przy reniferach. Jak już wspomniano, kobiety zbierały się też w jednym namiocie i zajmowały szyciem, robieniem na drutach, wyszywaniem oraz tkaniem ubrań i elementów wyposażenia domu. Pisarka bierze udział w tych pracach i zachwyca się umiejętnościami i zdolnościami Saamek, w szczególności zaś tkaniem za pomocą prymitywnego krosna (szw. bandgrind, bandkam):

Krosno. To narzędzie nie zasługuje na taką nazwę, ale właściwie nie wiem, jak je nazwać. Najbardziej podobne jest do bardzo dużego, rzadkiego grzebienia [...] z rogów reniferów. Zęby tego grzebienia są szeroko rozstawione i nie zawsze równe, a na nich jest osnowa. Z jednej strony przyczepia się ją do paska osoby, która tka, a z drugiej do patyka, który po prostu stawia się na ziemi i przytrzymuje stopą, żeby się nie przewrócił (s. 167-168, tłum. M.Ch.).

Dokładnie takiego krosna używa Marja, przy czym jedyna różnica polega na tym, że jedna strona osnowy jest przytwierdzona nie do patyka, a do rosnącej w pobliżu brzozy, ponieważ dziewczyna tka na zewnątrz, a nie w namiocie (36:30).

\section{Szkoła (język, zatrudnienie)}

W książce Kåtornas folk mamy do czynienia z innym rodzajem szkoły dla dzieci saamskich niż w filmie. Jest to związane z opisywaną wcześniej regulacją z 1917 roku wprowadzającą szkoły stacjonarne dla dzieci Saamów wędrujących, co spotkało się z wieloma protestami społeczności saamskich. W szkołach mogli uczyć zarówno nauczyciele pochodzenia szwedzkiego, jak i saamskiego.

Nordström uczyła w tzw. szkole nomadycznej, która mimo swojej nazwy przez cały okres nauki funkcjonowała $\mathrm{w}$ jednym miejscu, $\mathrm{t}$. $\mathrm{w}$ obozie letnim. Po lekcjach dzieci wracały do swoich rodzin i mogły używać języka saamskiego.

W filmie Syn nocnego słońca nie ma miejsca na pokazanie wielu szczegółów życia szkolnego, ponieważ pracę Marji oglądamy zaledwie w dwóch scenach (16:24-20:51). Marja jest nauczycielką w szkole stacjonarnej w Karesuando mieszczącej się w budynku o kształcie namiotu saamskiego (również nazywanego kåta), w którym dzieci uczą się i śpią oraz - jak można się domyślać - również spożywają posiłki, ponieważ znajduje się w nim piec do gotowania (16:21). Marja prowadzi lekcję języka szwedzkiego, na której dzieci czytają między innymi wiersz szwedzkiego poety Haralda Jacobsona: „Szwecja to wszystko, co mam. Nigdy nie czuje się sam, choć na talerzu ostatki, wiary nam nigdy nie zbraknie" (17:04). Dzieci czytają płynnie i dość szybko, ale być może nie rozumieją czytanego tekstu. Kiedy 
Nordström rozpoczęła naukę z dziećmi, zauważyła, że choć potrafiły dobrze czytać, nie rozumiały znaczenia poszczególnych słów - poprzedni nauczyciele stosowali metodę uczenia się na pamięć wymowy bez zrozumienia tekstu (s. 116).

W przerwie dzieci wybiegają przed namiot, aby jeździć na nartach i bawić się w „łapanie reniferów” (szw. renleken). Nordström opisuje zabawę dokładnie tak, jak wygląda ona w filmie: jest to rodzaj gry w berka, dzieci biegają, niektóre $\mathrm{z}$ kawałkami poroża reniferów $\mathrm{w}$ rękach, a jedno $\mathrm{z}$ nich stara się złapać róg lub inne dziecko na lasso (s. 33, 18:23).

\section{Język}

Saamowie w obu analizowanych tekstach kultury mówią między sobą po saamsku, najprawdopodobniej i filmie, i w książce używa się tego samego wariantu języka saamskiego, ponieważ występują w nim podobne wyrazy, na przykład przywitanie boris, boris (s. 100, 129, 1:16:00). Według współczesnego słownika saamskiego jest to powitanie $\mathrm{z}$ wariantu lulesamiska. W pozostałych współczesnych szwedzkich wariantach (nordsamiska, sydsamiska, umesamiska) powitanie brzmi podobnie, ale nieco inaczej ${ }^{7}$ (Samiskt informationscentrum 2021a). W filmie i w książce przedstawiono również gest witania się Saamów: obie witające się osoby kładą jedną dłoń na ramieniu drugiej (s. 100, 3:50).

Nordström musiała nauczyć się podstaw języka fińskiego, aby dostać posadę nauczycielki saamskich dzieci. Pisarka zauważa, że w formie pisemnej większość Saamów porozumiewa się po fińsku, ponieważ język saamski nie ma swojej formy pisanej (s. 42) ${ }^{8}$. Z otoczeniem zewnętrznym Saamowie w filmie kontaktują się w języku fińskim lub szwedzkim. W filmie Nila posługuje się fińskim w sklepie, w którym zatrzymał się w drodze do Kiruny (15:06), a z urzędnikami w Kirunie (22:24) i z pielęgniarką (1:04:44) rozmawia po szwedzku, natomiast Marja rozmawia po fińsku z lekarzem. Szwedzki był oczywiście w tym czasie językiem urzędowym, dlatego był obowiązkowy w szkołach saamskich. W filmie widzimy również, że urzędnik spisuje zeznanie Saamów oskarżonych o kradzież reniferów po szwedzku, a następnie Saamowie je podpisują (1:14:18).

Trzeba jednak zauważyć, że współczesne warianty języka saamskiego mogą różnić się od tych, którymi mówiono w 1914 i w 1939 r. W pierwszej połowie XX w. języki te były prawdopodobnie bardziej do siebie podobne niż obecnie. Od czasu powstania książki i filmu pogorszyła się sytuacja językowa Saamów, np. z powodu wspomnianego w artykule zakazu mówienia po saamsku $\mathrm{w}$ szkołach $\mathrm{z}$ internatem czy w wyniku przesiedleń.

8 Pisana forma saamskiego powstała dopiero w latach 50. XX w. (Samiskt informationscentrum 2021c). 


\section{Joik (tradycje)}

Bardzo ważnym elementem kultury saamskiej przedstawionym zarówno w książce Kåtornas folk, jak i w filmie Syn nocnego stońca jest joik, czyli tradycyjny śpiew, który „był sposobem opowiadania i opisywania zwierząt, ludzi, wydarzeń, zjawisk paranormalnych, relacji etc." (Stoor 2016: 711, tłum. M.Ch.). Badaczka teatru saamskiego Maria Sibińska opisuje joik jako szczególną formę „,łłowno-muzycznej ekspresji o prastarych korzeniach, łączącą się z różnymi poziomami saamskiej rzeczywistości - społecznym, religijnym i artystycznym" (Sibińska 2016: 237). Kiedy kraje nordyckie przeszły na protestantyzm, joik został praktycznie zakazany, między innymi dlatego, że towarzyszył szamanom saamskim (nåjdom), gdy wprowadzali się w trans, aby na przykład spotkać się z duchami przodków (Stoor 2016: 711; Sibińska 2016: 237). Krister Stoor cytuje saamskie legendy, według których diabeł zaczął jojkować, gdy został przez Boga strącony z nieba, a potem nauczył tego Saamów. Dlatego też Saamowie, którzy są chrześcijanami, nie jojkują (Stoor 2016: 711).Takie podejście do joikowania mają pobożni Saamowie w książce Kåtornas folk - pomocnica nauczycielki Saamka Ellekare tłumaczy jej, że każdy kaznodzieja uważa joik za grzech. Sama Nordström jest innego zdania i wyjaśnia dziewczynie, że nie może być grzechem wychwalanie stworzenia boskiego: słońca, nieba i śniegu, ale Ellekare nie daje się przekonać (s. 45). W innym fragmencie książki Nordström opisuje opowiadaną przez Ellekare historię o dziewczynie, która była próżna i joikowała, aż pewnego razu zachorowała i zmarła (s. 52). Interesujące wydarzenie związane z joikiem jest opisane pod koniec książki. Nordström zbiera drewno nad jeziorem i słyszy piękny joik śpiewany przez jedną z młodych kobiet saamskich. Pisarka jest nieco zdziwiona i stwierdza, że dziewczyna chyba nie wie, że ktoś ją słyszy, ponieważ - jak zauważa dalej sarkastycznie -,jest to wielki i straszny grzech od czasów zwycięskiego przybycia chrześcijaństwa - [joik - przyp. M.Ch.] jest grzeszny, jest nieczysty i królestwo niebieskie nie czeka raczej na tego, kto złamie ten zakaz" (s. 216-217). Nordström wykorzystuje tę sytuację, aby wyrazić swoją dezaprobatę wobec niezrozumiałych dla niej obiekcji kościoła, a jednocześnie zachwyt nad tego rodzaju śpiewem:

Gdy nikt nie słyszy, płynie joik z ich ust, stają się improwizatorami Bożej łaski. Melodia, i słowa kształtowane przez wewnętrzny ogień [...]. Jak Marja teraz! Przecież musi joikować w taki wieczór jak ten, gdy gwiazdy świecą na zachodzie, jezioro jak szklana tafla, gdy góry lśnią biało-błękitne [...]. Przecież musi śpiewać o tym wszystkim, żeby jej serce nie pękło z młodości i szczęścia. [...] „Vasti, vasti! - powiedzieliby starsi, gdyby ją usłyszeli - Brzydko! Brzydko!” (s. 217, tłum. M.Ch.).

Dwa dni po tym wydarzeniu Marja nagle zachorowała i nie mogła dojść do siebie, mimo starań Nordström, która miała zapas szwedzkich leków. Pomaga dopiero puszczanie krwi przez starszą Saamkę. Nigdzie w książce autorka nie mówi wprost, że choroba była karą za joik, ale w jakiś sposób to sugeruje poprzez zestawienie ze sobą opowieści o tych dwóch sytuacjach (s. 216-230). 
O ile w reportażu nie dziwi występowanie tradycyjnego śpiewu saamskiego, mimo że był on zakazany, o tyle przedstawienie go w fikcji z 1939 roku jest niespotykane. W filmie Syn nocnego słońca słychać joik w dwóch krótkich fragmentach, które nie są w żaden sposób skomentowane. Po raz pierwszy w filmie joikuje matka Marji, patrząc, jak jej córka odchodzi ze świeżo poślubionym mężczyzną (20:38), czyli w momencie ważnym zarówno dla samej dziewczyny, jak i jej matki. Druga scena, w której pojawia się joik, nie jest już tak znacząca - Labba śpiewa w trakcie samotnej drogi powrotnej z miasta, w którym załatwiał sprawy urzędowe; jest lato, piękna pogoda i Saam uśmiecha się szeroko, śpiewając (37:17).

Joik w filmie dziwi, ponieważ występujący w Synu nocnego słońca Saamowie (podobnie jak Saamowie, wśród których mieszkała Nordström) należeli do wyznania laestadiańskiego, którego założyciel Lars Levi Læstadius zakazywał joikowania (Stoor 2016: 715). Według reżysera Rolfa Husberga uzyskanie zgody na wystąpienie tej grupy Saamów w filmie wymagało kilkumiesięcznych rozmów między innymi z pastorem (Husberg 1975).

Scena, w której Labba joikuje, poprzedza ciąg katastrof nadciągających na Saamów, między innymi niedługo potem zostają ukradzione ich renifery. Nila odzyskuje stado, ale po jakimś czasie trafia do więzienia oskarżony o zabójstwo złodzieja, który utonął. Twórcy nie sugerują jednak w żaden sposób, że przyczynił się do tego śpiew Labby, czego można by się spodziewać, biorąc pod uwagę, że wszelkie inne momenty filmu mające wydźwięk edukacyjny są przez scenarzystów wykorzystane i opatrzone odpowiednim pouczeniem narratora.

Przedstawienie joiku w filmie może być spowodowane chęcią egzotyzacji Saamów, ale może też wynikać z dużego zainteresowania joikiem na początku $\mathrm{XX}$ wieku. Stoor opisuje kilku dokumentalistów fińskich, niemieckich i szwedzkich, którzy w tym okresie jeździli i transkrybowali joik (Stoor 2016: 719-720)99.

\section{Duchowość i religia}

Jak wspomniałam wcześniej, Saamowie biorący udział w filmie, a także bohaterowie reportażu Nordström byli głęboko religijni. W filmie przedstawiono jednak jedynie bardzo krótką scenę ślubu kościelnego oraz pacierz odmawiany przed snem przez

9 To dychotomiczne podejście do tradycyjnego śpiewu Saamów przedstawiła saamska reżyserka Amanda Kernell w filmie Krew Saamów (2016). Film ukazuje politykę państwa szwedzkiego wobec Saamów w latach 30. XX w. na przykładzie nastoletniej Elle Marji. Gdy młodsza siostra bohaterki ma rozpocząć naukę w szkole z internatem, Elle Marja przestrzega ją przed joikowaniem w szkole (15:42). W późniejszej scenie dwie szwedzkie studentki antropologii nalegają, aby Elle Marja zaśpiewała dla nich joik, którego nigdy nie słyszały, co dziewczyna robi bardzo niechętnie (01:26:20). W jednej ze scen, których akcja toczy się w czasach współczesnych, słuchamy joiku mężczyzny śpiewającego na pogrzebie w kościele (3:35), co można odczytać jako mocną deklarację twórców filmu, ponieważ nawet w XXI w. joikowanie w kościele potrafi wywoływać kontrowersje i napotykać na opór (Stoor 2016: 713). 
dzieci szkolne (25:14, 2:23). Natomiast Saamowie w reportażu korzystają z odwiedzin wędrownych pastorów - biorą wtedy udział w nabożeństwach w namiocie i wpadają w rodzaj religijnego transu (s. 232-234).

Bohaterowie filmu rozwiązują problemy w sposób świecki i racjonalny - gdy Marja choruje, Nila próbuje wezwać lekarza, a następnie wiezie ją do szpitala (1:08:59). Gdy Nila trafia do więzienia, Labba jedzie do Sztokholmu prosić króla o wstawiennictwo (1:15:14).

Nåjd, czyli saamski szaman, nie występuje w żadnym $\mathrm{z}$ analizowanych tekstów kultury. W książce Kåtornas folk sama Nordström staje się lekarzem Saamów po tym, gdy kilka razy udało jej się pomóc chorym dzięki wykorzystaniu konwencjonalnej wiedzy medycznej z tego okresu. Kiedy środki zastosowane przez pisarkę nie działają, Saamowie zwracają się do starszych osób, które „coś wiedzą”. Jest tak we wspomnianym już przypadku Marji, gdy wzywa się Gammel-Inkę, która „coś wie", a gdy choruje pies, wezwany zostaje Matte. Gammel-Inka puszcza Marji krew, co w tym okresie nadal robiło wielu lekarzy, ale podobnie jak Matte w przypadku chorego psa odprawia także różne rytuały, których autorka reportażu nie rozumie (s. 75). W obu sytuacjach działania te prowadzą do wyzdrowienia, czego Nordström nie komentuje w żaden sposób. Podobnie jest, gdy opowiada Saamom, że słyszała na pustkowiu bicie dzwonów kościelnych, co według nich oznacza śmierć kogoś bliskiego. Zaledwie kilka tygodni później pisarka dowiaduje się o śmierci ojca (s. 256). Dużo bardziej sceptycznie Nordström podchodzi do złych trolli uldat, o których opowiadają Saamowie. Wielu widziało uldat, ale zdaniem Saamów nie spotyka się ich już tak często, „bo boją się chrześcijaństwa” (s. 251) ${ }^{10}$.

W filmie przedstawiono jeden rodzaj obrzędu pochodzący prawdopodobnie z pogańskich czasów, którego funkcjonowanie w latach 30. XX wieku należałoby jednak podać w wątpliwość. Gdy grupa Saamów, z którą wędruje Nila, traci dużą część stad, dziadek Marji decyduje się na samotną śmierć: „Nonje wstaje, wszyscy wiedzą, co zamierza, ale nikt go nie powstrzymuje" (11:34). Nonje wychodzi z namiotu na burzę śnieżną, spełnia „swoją ostatnią powinność”, wieszając „swojego wiernego psa", i idzie przed siebie, aż w końcu pada w śnieg i umiera (13:04).

Nie znalazłam w źródłach opisów tego typu śmierci osób starszych wśród Saamów w tym okresie. W artykule Oblicza starości Urszula Lehr pisze o podobnych zwyczajach na półwyspie skandynawskim w pierwszych wiekach naszej ery, gdy umieranie ze starości i choroby traktowano jako niehonorowe i dlatego „utrzymywanie starców nie było pozytywnie oceniane" (Lehr 2003: 78) ${ }^{11}$. W gminie Åsele na północy Szwecji znajduje się skała o nazwie Offerhällan, czyli klif ofiarny, który

10 O wierze w podziemny lud wyglądający i żyjący dokładnie tak jak Saamowie pisze również fiński etnograf Samuli Paulaharju (1934). Mieli oni być potomkami dzieci Adama i Ewy schowanymi przez Ewę (Paulaharju 1972: 93-94).

11 O zabijaniu przez Saamów starców niezdolnych do wędrówki pisze Andrzej Pilipiuk w książce Raport z Pótnocy (2017), ale zaznacza, że zwyczaj ten zanikł po wprowadzeniu chrześcijaństwa; jest to jednak książka podróżnicza i autor nie podaje źródła tej informacji. 
uważa się za miejsce samobójstw starszych Saamów. Sama gmina podaje jednak na swojej oficjalnej witrynie internetowej, że nazwa ta pochodzi „z opowieści” (Bergvattenberget 2021).

\section{Zakończenie i wnioski}

Wiele przedstawionych przeze mnie podobieństw w analizowanych filmie i książce wskazuje na rzetelne przedstawienie elementów tożsamości etnicznej Saamów w 1916 i 1939 roku. Nie wyklucza to jednak faktu, że z dzisiejszej perspektywy widzimy w tych tekstach kultury przykłady egzotyzacji Saamów oraz spojrzenie kolonialne i paternalistyczne. Egzotyzacja według badaczki kolonializmu Agaty Lubowickiej jest w tym przypadku sposobem „zachodniego świata, by utrwalić Innego w jego egzotycznej postaci” (Lubowicka 2011:100). Saamowie w filmie są prości, naiwni i łatwowierni, a król szwedzki jak dobry ojciec ratuje Nilę od niesłusznych oskarżeń. Ten sposób obrazowania wpisuje się w funkcjonującą w tym okresie tendencję przedstawiania Saamów w filmie:

Filmy z lat 20. XX wieku reprezentują kulturę Saamów jako ambiwalentną, od reprezentacji demonizującej po romantyzującą. Zgadzało się to z dominującym podejściem do kultury Saamów w okresie międzywojennym (Mecsei 2015: 74, tłum M.Ch.)

Film Syn nocnego słońca, który jest w chwili pisania artykuły w ofercie platformy Netflix, nie demonizuje Saamów, ale - jak wykazałam - są w nim pewne elementy egzotyzujące. Film nie wzbudził takich dyskusji, jakie pojawiły się po ponownym wydaniu książki Katornas folk w 2013 roku. Jak wspomniałam wcześniej, recenzje książki w 1916 roku były pozytywne, nie sposób jednak nie zauważyć w nich charakterystycznego dla tego okresu kolonialnego tonu. Szczególnie Ernst Klein, recenzent pisma kobiecego Idun, podkreślał wyższość Szwedów nad Saamami. Prawie połowę tej recenzji zajęły pochwały narodu szwedzkiego i jego miłości do natury, której równać może się tylko ta obserwowana wśród Anglików. Autor uznał, że nie ma nacji, która „byłaby bardziej odpowiednia jako sąsiedzi Lapończyków niż Szwedzi” (Klein 1916: 829, tłum. M.Ch.). Klein nazywa również Saamów „prymitywniejszym narodem” (1916: 830, tłum. M.Ch.) i próbuje na swój kolonialny sposób wyjaśnić przyjaźń i przywiązanie autorki do grupy ludzi, z którą przeżyła pół roku: „Tak bardzo kocha to pustkowie i ten lud, że widzi ich tylko w pozytywnych barwach" (1916: 829, tłum. M.Ch.).

Książka podobała się również działającemu w Laponii głównemu adwokatami higieny rasowej doktorowi Hermanowi Lundborgowi, który uważał, że opisy Nordström wspierały jego sprawę (Bremmer 2017: 142), chociaż w treści książki trudno jest znaleźć uzasadnienie dla tego typu twierdzeń. Natomiast Karin Stenberg, nauczycielka saamska, a w późniejszych latach główna działaczka na rzecz równych 
praw Saamów w Szwecji, uważała, że opisy Nordström umacniały uprzedzenia Szwedów, ale przede wszystkim, że przedstawiła ona Saamów jako lud, który nie dąży do żadnej zmiany swojego status quo (Bremmer 2017: 143) ${ }^{12}$. Z jednej strony należy podkreślić, że ocena książki przez Saamów i ich legitymizacja tej publikacji nie powinna podlegać dyskusji, ale z drugiej trzeba zauważyć, że dla ludu przez wieki dyskryminowanego i uciskanego nawet jedno zdanie w trzystustronicowej książce może przekreślić jej pozytywny wydźwięk.

Książka Nordström miała wiele wydań, ostatni raz opublikowano ją w 2013 roku w wydawnictwie Bakhåll. Publikacja ponownie została przyjęta bardzo pozytywnie, a jedyny wyjątek stanowiły dwa artykuły dramatopisarza Erika Norberga w gazecie Aftonbladet (Norberg 2014a; Norberg 2014b). W pierwszym artykule Norberg stwierdza, że reportaż „pławi się w kolonializmie” oraz przenikają go idee segregacji. Kilka dni później wydawnictwo Bakhåll odpowiedziało krótko na krytykę (Redakcja Bakhåll 2014), stwierdzając m.in.:

Większość osób piszących o innych kulturach wie, że nie MOŻNA pisać z innej perspektywy niż własna. Można natomiast dołożyć starań, aby pisać z jak największą otwartością i uczciwością, co zrobiła Ester Blenda Nordström, ale nie była ona w stanie pisać z perspektywy Saamów, ponieważ de facto nie była Saamką (tłum. M.Ch).

Inne argumenty Norberga wydają się oparte na fragmentach wyrwanych z kontekstu. Dramaturg pisze na przykład, że Nordström „nie podobają się zbyt szwedzkie podręczniki. Lapończycy nie muszą się uczyć o świecie zewnętrznym” (Norberg 2014a, tłum. M.Ch.). Tymczasem pisarka bardzo dokładnie motywuje swoją niechęć do szwedzkich podręczników argumentami, które dzisiaj są oczywiste dla każdego, kto zajmuje się nauczaniem dzieci. Według Nordström w podręcznikach powinno być więcej ilustracji i opowiadań ze świata znanego dzieciom saamskim, ponieważ zachęciłoby je to do nauki. W ten sposób dzieci mogłyby się uczyć o „innych częściach Szwecji, o których nic nie wiedzą, o królu i o Riksdagu [...], o samych Lapończykach i ich pochodzeniu, o innych ludach rdzennych i ich życiu, o hodowli reniferów, o służbie zdrowia - całkowicie nieznany temat w Laponii, o słońcu, księżycu i stu innych rzeczach” (Nordström 1916:191, tłum. M.Ch.). Jak widać, autorka nie odmawiała nauki o świecie dzieciom saamskim, które uważała za „najpracowitszych i najzdolniejszych uczniów”, jakich można sobie wyobrazić (Nordström 1916:191, tłum. M.Ch.).

Inną kwestią krytykowaną przez Norberga w reportażu Nordström jest brak potępienia higieny rasowej propagowanej w czasach pisarki. Książka Nordström nie jest jednak krytyką społeczną, a szczegółowym opisem jej życia wśród Saamów, codziennych obowiązków, nauczania w szkole, wędrówki. Zgodzę się tutaj raczej

12 Obrazuje to obraźliwe dziś szwedzkie powiedzenie „Lapp ska vara lapp”, czyli „Lapończyk ma pozostać Lapończkiem”. Ten punkt widzenia prezentuje państwo szwedzkie przedstawione we wspomnianym filmie Krew Saamów (2016). 
z innym recenzentem, który stwierdza, że dziennikarka „wchodzi w kulturę”, a „spojrzenie kolonialne jest jej obce” (Sjöberg 2013: 31, tłum. M.Ch.). Nie jest rzeczą dziwną, że Nordström nie zawarła w książce informacji o podejmowanych wobec Saamów działaniach eugenicznych i niechęci biologów rasowych do „mieszania się" Saamów z etnicznymi Szwedami, ponieważ były to początki popularności tej pseudonauki w Szwecji. Instytut Biologii Rasowej, którego dyrektorem został wspomniany Lundborg, został założony w 1921 roku (Samiskt informationscentrum 2021d). Nordström była natomiast oburzona dyskryminacją Saamów - w książce opisuje sytuację, gdy w hotelu odmówiono wynajęcia pokoju dla niej i dla jej saamskiej towarzyszki (Nordström 1916: 128) ${ }^{13}$.

W filmie kręconym w 1938 roku takie wątki mogłyby się oczywiście pojawić, bo higiena rasowa była już wtedy w Szwecji rozpowszechniona, trudno jednak spodziewać się tego w przygodowym filmie fabularnym, który podobnie jak książka nie był krytyką społeczną. W tym okresie właściwie nie było głosów przeciwnych higienie rasowej, a wiele działań eugenicznych ukrywano przed społeczeństwem szwedzkim.

Jak widać z przedstawionych reakcji na analizowane teksty kultury, zarówno na początku XX wieku, jak i współcześnie dużo większe wymagania stawia się reportażowi, umniejszając rolę fikcji w kształtowaniu obrazu świata Saamów, chociaż to właśnie w owej fikcji jest on dużo bardziej schematyczny. Jak pokazują współczesne badania, nie należy lekceważyć fikcji jako elementu mającego duży wpływ na wiedzę widzów, słuchaczy i czytelników (Burzyńska, Binkowska-Bury i Januszewicz 2015; Ward i Aubrey 2017), a w przypadku filmu Syn nocnego słońca również na współczesnych widzów platformy Netflix, którzy sięgną po tę ofertę. Ponieważ jednak rekonstrukcja elementów tożsamości jest bardzo podobna w obu tekstach kultury, można mieć nadzieję, że spotkanie z filmem pozostawi w widzach realistyczny obraz kultury Saamów z początku XX wieku.

\section{Bibliografia}

Bergvattenberget, Åsele kommun, https://www.asele.se/fritid-turism-och-kultur/fritidsaktviteter/ vandringsleder/offerhallan/ (dostęp: 5.04.2021).

Bremmer, F. (2017). Ett jävla solsken: En biografi om Ester Blenda Nordström. Stockholm: Bokförlaget Forum.

Burzyńska, J., M. Binkowska-Bury i P. Januszewicz. (2015). Television as a source of information on health and illness - review of benefits and problems. Progress in Health Sciences 5(2): 174-184.

13 Dopiero współcześnie powstają teksty kultury, takie jak: filmy fabularne, książki, seriale dokumentalne, które rzetelnie pokazują kwestię dyskryminacji i segregacji Saamów oraz rolę państwa szwedzkiego w tym procesie, zob. film Krew Saamów (2016), książka Elin Anny Labba Herrarna satte oss hit (Labba 2020) i serial dokumentalny Tvångsförflyttningar - Bággojohtin (2019) o przesiedleniach Saamów. 
Chandra, K. (2006). What is Ethnic Identity and Why Does it Matter? Annual Review of Political Science 9: 397-424.

Güettler, K. (2020). Flera kopplingar i Sápmi. Kalle Güettler, författare, https://kalleguettler. wordpress.com/2020/01/29/flera-kopplingar-i-sapmi/ (dostęp: 2.04.2021).

Horowitz, L.D. (1985). Ethnic Group in Conflict. Berkley-Los Angeles-London: University of California Press.

Irobi, E.G. (2009). Konflikty etniczne w Afryce w świetle teorii potrzeb ludzkich. Krakowskie Studia Międzynarodowe 1: 232-244.

Jordahl, J. (2014). Hon fick samelivet att kännas ända in på huden. Aftonbladet, 23. stycznia 2014. https://www.aftonbladet.se/kultur/a/m6zwaL/hon-fick-samelivet-att-kannas-anda-in-pa-huden (dostęp: 6.04.2021).

Klein, E. (1916). Kåtornas folk. Idun, 24. grudnia 1916.

Labba, E.A. (2020). Herrarna satte oss hit. Stockholm: Norstedts.

Lehr, U. (2003). Oblicza starości. Etnografia Polska 47(1-2): 71-102.

Legare, A. (2013). The Reconstruction of Inuit Collective Identity: From Cultural to Civic: The Case of Nunavut. W: J.P. White, S. Wingert, D. Beavo i P. Maxim (red.). Volume 4: Moving Forward, Making a Difference. Seria: Aboriginal Policy Research. Ottawa: Thompson Educational Publishing, s. 103-121.

Lubowicka, A. (2011). Anaruk i Odarpi - szlachetne dzikie dzieci w eskimoskim skansenie. Z problematyki egzotyzacji eskimoskiej w polskie literaturze. W: H. Chojnacki, A. Kubka, E. Mrozek-Sadowska i M. Sibińska (red.). W poszukiwaniu tożsamości skandynawskiej i polskiej. Studia o literaturze i społeczeństwie. Gdańsk: Wydawnictwo Uniwersytetu Gdańskiego, s. $99-115$.

Mccann-Mortimer, P., M. Augoustinos i A. Lecouteur. (2004).'Race' and the Human Genome Project: Constructions of Scientific Legitimacy. Discourse \& Society 15(4).

Mecsei, M.K. (2015). Cultural Stereotypes and Negotiations in Sámi Cinema. W: S. MacKenzie i A. Westerståhl Stenport (eds.). Film on Ice: Cinemas of the Arctic. Edinburgh: Edinburgh University Press.

Norberg, E. (2014a). Samer utmålas som obildade och barnsliga. Aftonbladet, 11. stycznia 2014. https://www.aftonbladet.se/debatt/a/21j06R/samer-utmalas-som-obildade-och-barnsliga (dostęp: 31.03.2021).

Norberg, E. (2014b). Groteskt att kalla boken en hyllning. Aftonbladet, 15. stycznia 2014. https://www.aftonbladet.se/debatt/a/a2KB3M/groteskt-att-kalla-boken-en-hyllning (dostęp: 31.03.2021).

Nordström, E.B. (1916). Kåtornas folk [Lud namiotów]. Stockholm: Wahlström \& Windstrand.

Oscarsson, E.O. (2016). Kåtasystemet ägde det allra närmaste samband med lapparnas sedvänjor. W: K. Huuva i E. Blind (red.). "När jag var åtta år lämnade jag mitt hem och jag har ännu inte kommit tillbaka” Minnesbilder från samernas skoltid. Stockholm: Verbum, s. 85-108.

Paulaharju, S. (1934). Tunturien yöpuolta: vanhoja tarinoita. Helsinki: Porvoo.

Paulaharju, S. (1972). Nocne cienie tunturi. Tłum. C. Lewandowska. Poznań: Wydawnictwo Poznańskie.

Pilipiuk, A. (2017). Raport z Pótnocy. Lublin: Fabryka Słów.

Redakcja Bakhåll. (2014). Boken är en hyllning till samerna. Aftonbladet, 13. stycznia 2014. https://www.aftonbladet.se/debatt/a/4dWKMe/boken-ar-en-hyllning-till-samerna (dostęp: 31.03.2021).

Roderick. (1939). Midnattssolens Son. Svenska Dagbladet, 8. grudnia 1939.

Samiskt informationscentrum. (2021a). Språk, dialekt eller varietet, http://www.samer.se/1186 (dostęp: 2.04.2021).

Samiskt informationscentrum. (2021b). Sápmi, http://www.samer.se/1002 (dostęp: 2.04.2021). 
Samiskt informationscentrum. (2021c). Att skriva på samiska, http://www.samer.se/skriftspraket (dostęp: 4.04.2021).

Samiskt informationscentrum. (2021d). Långa skallar och korta samer, http://www.samer. se/1028 (dostęp: 4.04.2021).

Sibińska, M. (2016). Saamskie teatry: między lokalnością a obcością? Folia Scandinavica 19: 233-249.

Sjöberg, F. (2013). Kärv vildmarskromantik. Svenska Dagbladet, 19. grudnia 2013.

Stoor, K. (2016). Svenska kyrkan och jojken. W: D. Lindmark i O. Sundström (red.). De historiska relationerna mellan Svenska kyrkan och samerna: en vetenskaplig antologi. Skellefteå: Artos \& Norma bokförlag, s. 711-735.

Suchocka, R. (2017). Meandry etnicznych i narodowych identyfikacji. Opuscula Sociologica 3(21): 5-18.

Midnattssolensson. Svensk filmdatabas. http://www.svenskfilmdatabas.se/sv/item/?type=film\&itemid=3896\#censorship (dostęp: 4.04.2021).

Ward, L.M. i J.S. Aubrey. (2017). Watching gender: How stereotypes in movies and on TV impact kids' development. San Francisco, CA: Common Sense.

Wójcicka, M. (2016). Tożsamość w procesie komunikacji. Artes Humanae 1: 55-67.

\section{Filmografia}

Ester Blenda - walraffande piga [Ester Blenda - dziennikarka śledcza w przebraniu służącej]. (2016). [film dokumentalny]. Reżyseria: A. Hylander. Szwecja.

Midnatssolens son (Syn nocnego słońca). (1939). [film fabularny]. Reżyseria: R. Husberg, T. Brooks. Szwecja.

Midnight Sun [Dzień polarny]. (2016). [serial]. Reżyseria: M. Mårlind, B. Stein. Francja, Szwecja. Sameblod (Krew Saamów). (2016). [film fabularny]. Reżyseria: A. Kernell. Dania, Norwegia, Szwecja.

Tvångsförflyttningar - Bággojohtin [Przymusowe przesiedlenia - Baggojohtin]. (2019). [serial dokumentalny]. Szwecja. 